\title{
Nutritional and Functional Potential of Selliera radicans Cav., a Chilean Native Halophyte
}

\author{
Maria del Pilar Caramantin Soriano ${ }^{1, *}$, Flavia Schiappacasse ${ }^{2}$, Patricio Peñailillo ${ }^{3}$, Jaime Tapia ${ }^{4}$, Sergio \\ Wehinger ${ }^{5}$, Camilo A. Valenzuela-Vasquez², and Sarvia M. Durán-Peña²
}

\section{Maria del Pilar Caramantin \\ Soriano ${ }^{1, *}$, Flavia Schiappacasse ${ }^{2}$, Patricio Peñailillo3 ${ }^{3}$, Jaime Tapia ${ }^{4}$, Sergio Wehinger ${ }^{5}$, Camilo A. Valenzuela-Vasquez ${ }^{2}$, and Sarvia M. Durán-Peña ${ }^{2}$}

IInstituto de Química de Recursos Naturales, Universidad de Talca, Av. Lircay s/n, Talca, CHILE.

${ }^{2}$ Facultad de Ciencias Agrarias, Universidad de Talca, Talca, CHILE.

${ }^{3}$ Instituto de Ciencias Biológicas, Universidad de Talca, Talca, CHILE.

${ }^{4}$ Instituto de Química de Recursos Naturales, Universidad de Talca, Av. Lircay s/n, Talca, CHILE.

${ }^{5}$ Facultad de Ciencias de la Salud Departamento de Bioquímica Clínica e Inmunohematología, Universidad de Talca, Talca, CHILE.

\section{Correspondence}

\section{Maria del Pilar Caramantin Soriano}

Instituto de Química de Recursos

Naturales, Universidad de Talca, Av. Lircay s/n, Talca, CHILE.

E-mail: mcaramantin@utalca.cl

History

- Submission Date: 08-11-2020;

- Review completed: 30-12-2020;

- Accepted Date: 04-01-2021.

DOI : 10.5530/pj.2021.13.44

Article Available online

http://www.phcogj.com/v13/i2

\section{Copyright}

(C) 2021 Phcogj.Com. This is an openaccess article distributed under the terms of the Creative Commons Attribution 4.0 International license.

\section{ABSTRACT}

Background: Selliera radicans was recognized as one of the foods consumed by the oldest human settlement in America (Monte Verde, Chile) that had a diet with a high component of plants. Objective: This study aims at investigating nutritional and functional characteristics of $S$. radicans, a native halophyte from Chile. Materials and Methods: An analysis of total protein, carbohydrate, ash, and moisture from $S$. radicans leaves was performed, using standard methods. The content of macro and micronutrients was quantified by atomic absorption spectrometry. The inulin content was carried out based on the Seliwanoff reactions. S. radicans leaves were extracted with methanol and the total content of phenolic and flavonoids and antioxidant activity were evaluated by spectroscopic method. Results: Leaves from cultivated plants proved to be a suitable source of proteins (7.5\% on DW), ash (6.8\% on DW), and a wide range of macro and micronutrients, where $\mathrm{Ca}, \mathrm{K}$, and $\mathrm{Na}$ had the highest values. In addition, inulin (2.3\% on DW), total phenolics (63.4 GAE/g LDW) and flavonoids (21.8 QE/g LDW), and antioxidant capacity (10 TE/g LDW) were noted. Conclusions: According to the results, cultivated $S$. radicans leaves are promising sources of food with beneficial health properties.

Key words: Antioxidant activity, Goodeniaceae, Inulin, Macro and Micronutrients, Total Phenolics, Total Flavonoids.

\section{INTRODUCTION}

The wide range of edaphoclimatic variables that characterize Chile is reflected in its large and specific vegetal biodiversity. Only a small group of native plant species has been explored and studied. Therefore, there are still few scientific papers published about Chile's typical flora. ${ }^{1-3}$ Among the little studied species are the halophytes. ${ }^{4}$ Halophytes represent roughly $1 \%$ of the world's flora (both dicots and monocots) and are recognized for their ability to survive in saline environments. ${ }^{5}$ These plants are widely distributed in arid, semi-arid, and wetland regions, throughout the tropical and temperate areas of the planet. ${ }^{6-7}$ Traditionally, halophytes have been used as food and source of medicinal substances during the last centuries. ${ }^{8-9}$ Nowadays, halophytes are used as source of vegetable fibers, bio-fuel, as stabilizers or phytoextracters of heavy metals in bioremediation processes, as landscape plants and others purposes. ${ }^{10-14}$ According to eHALOPH data, in Chile there are 138 halophyte species distributed in 31 families, and more than $80 \%$ of these species are herbaceous and about $55 \%$ are exotic. ${ }^{4}$

Goodeniaceae is a Eudicot family in the order Asterales comprising more than twelve genera in the world and includes more than 400 species. Indigenous communities have traditionally utilized various species of this family for medicinal purposes. ${ }^{15-16}$ To many Goodeniaceae species are attributed pharmacological activities such as antidiabetic effect, anti-inflammatory, antiviral, antibacterial, antitumor, and others. ${ }^{17}$ Several secondary metabolites including coumarines, iridoid glycosides, monoterpenes, sesquiterpenes and other terpenes, such as pentacyclic triterpenes, flavones, alkaloids, anthocyanins, and others have been isolated and identified. ${ }^{17-20}$ Still in relation to secondary metabolites of Goodeniaceae species, Weber $(1955)^{21}$ reported the presence of inulin, a group of naturally occurring polysaccharides considered as a probiotic, in samples of Selliera radicans Cav.

Selliera radicans Cav. is a halophyte native to Australia, Chile and New Zealand. ${ }^{22}$ According to archaeological studies, fragments of edible seeds and stems of $S$. radicans together with a diverse range of other plant specimens, including wood artifacts, were found near Puerto Montt, in a site that would correspond to a habitat dating back 14500 thousand years, the oldest in its genre discovered in Chile..$^{23-24}$

In Chile, Selliera radicans grows naturally from region Atacama to region Aysén del General Carlos Ibañez del Campo, in riparian zones near rivers, lakes, and the sea. Local inhabitants know this creeping herbaceous plant as "hierba de las marismas". It is characterized by stolons that hold nodal fibrous roots, succulent green, shiny leaves, and small white flowers. It is easy to propagate, grows relatively quickly, and survives temporary flooding. In addition, it is used in landscaping as a groundcover in gardens and green roofs in houses. ${ }^{25}$ 
It has been observed that rabbit, black-necked swans, and other animals, consume the leaves of Selliera radicans. Thus, a chemical study was performed related to the nutritional and functional properties of Selliera radicans leaves, obtained from a controlled crop. There are no nutritional or phytochemical published studies involving Selliera radicans.

\section{MATERIALS AND METHODS}

\section{Collection of Plant material}

Leaves were collected from cultivated Selliera radicans in a polyethylenecovered greenhouse, located at the Universidad de Talca, Talca, Chile, and maintained at environmental temperature. The Selliera radicans plants grown in this greenhouse are originated from wild samples of this species collected from Vichuquén (Maule Region, $34^{\circ} 51^{\prime}$ SL- $72^{\circ} 00^{\prime}$ WL), Chile. The botanist Dr. Patricio Peñailillo identified this species and a voucher specimen (No. 3367) was deposited at the Herbarium Universidad de Talca.

\section{Nutrition and functional characterization}

Leaves of Selliera radicans were washed with tap water, dried in oven (Memmert ULM 700), grounded (Wiley ${ }^{\oplus}$ Mini-Mill, Thomas ${ }^{\circledR}$ ), and stored in dark bags at $-18^{\circ} \mathrm{C}$. Moisture content was measured according to the AOAC method. ${ }^{26}$ An empty container and the lid were dried in an oven at $106^{\circ} \mathrm{C}$ for $3 \mathrm{~h}$ and transferred to desiccators until cool and weight was recorded. Then, a sample of $S$. radicans was placed in the container and oven dried at $40{ }^{\circ} \mathrm{C}$ until constant weight. At the end of drying, the container with partially covered lid was transferred to a desiccator for cooling and the container weight was recorded as above. Ash content was calculated according to AOAC method. ${ }^{27}$ Crucible and the lid were left in the furnace at $555^{\circ} \mathrm{C}$ for $12 \mathrm{~h}$. The crucible was cooled in the desiccator for $1 \mathrm{~h}$ and weight was recorded. Weight of a sample of $S$. radicans and crucible was then recorded. Crucible with the sample was heated over low Bunsen flame with half covered lid and placed in a muffle furnace until fumes were no longer produced. Then the crucible was heated at $555^{\circ} \mathrm{C}$ for $12 \mathrm{~h}$, cooled in a desiccator and the weight was recorded. Total carbohydrates were analyzed by ultraviolet spectrophotometry, using UV-1800 Shimadzu Spectrophotometer, and following the method described by Morse. ${ }^{28} \mathrm{~A} 0.2 \%$ anthrone solution was prepared in concentrated sulfuric acid and then stored in a dark bottle in the refrigerator. Standard solutions were prepared by serial dilutions of a glucose stock solution of $200 \mathrm{mg} \mathrm{L}^{-1}$. Methanol extract of $100 \mathrm{mg}$ of dried and ground leaves from $S$. radicans were obtained by sonication (30 minutes). Subsequently the methanol extract was centrifuged at $800 \mathrm{rpm}$. The absorbance of the solution was measured in a spectrophotometer at a wavelength of $630 \mathrm{~nm}$, against a target prepared under the same conditions of the sample. The total nitrogen content in $S$. radicans leaves was determined following the Dumas method using the analyzer equipment TruSpec micro CN (LECO). ${ }^{29}$ Crude protein was calculated by multiplying the evaluated nitrogen by 6.25. The content of $\mathrm{Ca}, \mathrm{Na}, \mathrm{K}, \mathrm{Mg}, \mathrm{Fe}, \mathrm{Zn}, \mathrm{Cu}$ and $\mathrm{Mn}$ was spectrophotometrically determined using an atomic absorption equipment (Agilent 280FS AA). ${ }^{30}$ For the analysis of inorganic substances, samples of Selliera radicans leaves were washed with bidistilled water. $1.000 \mathrm{~g}$ of leaves was calcined in a muffle for 6 hours at $500{ }^{\circ} \mathrm{C}$. The calcined sample was cooled in a desiccator, and then transferred to an Erlenmeyer flask. The cold ash was diluted with $10 \mathrm{~mL}$ of $2 \mathrm{~N} \mathrm{HCl}$, and subsequently heated to boiling. Once the sample was cooled, it was filtered and reconstituted up to $50 \mathrm{~mL}$ with pure water in a measuring flask, obtaining the treated sample ready for the direct analysis of the essential microelements by atomic absorption spectrometry. Before measuring the macroelements concentration $(\mathrm{Ca}$, $\mathrm{Mg}, \mathrm{K}$ and $\mathrm{Na}$ ) in the AAS, a 1:10 v/v dilution of the sample was performed with $\mathrm{La}_{2} \mathrm{O}_{3}\left(1.1 \mathrm{~g} \mathrm{~L}^{-1}\right.$ solution). $\mathrm{Mn}, \mathrm{Cu}, \mathrm{Fe}$ and $\mathrm{Zn}$ were determined with no dilution because of their low concentration. Boron and phosphorus were analyzed using a UV-VIS Spectrophotometer (Agilent 8454), in accordance with colorimetric method. ${ }^{31-33}$ Boron content was determined in a leaves tissue extract of $S$. radicans obtained from dry ashing in a muffle furnace at $550{ }^{\circ} \mathrm{C}$ for $1 \mathrm{~h}$ and subsequent extraction with $0.36 \mathrm{~N} \mathrm{H}_{2} \mathrm{SO}_{4}$. Then, $5 \mathrm{~mL}$ of leaves extract were mixed with $2 \mathrm{~mL}$ of ammonium acetate buffer ( $\mathrm{pH} 5.5$ ), and $2 \mathrm{~mL}$ of $0.02 \mathrm{M}$ EDTA in a B-free test tube and vortexed. Then to the resulting mixture was added $1 \mathrm{~mL}$ of azomethine- $\mathrm{H}$ reagent $(0.9 \%$ azomethine- $\mathrm{H}+2 \%$ ascorbic acid solution). It was vortexed gently and the resulting solution was allowed to stand for $1 \mathrm{~h}$ at room temperature, and vortexed again, and the readings were taken at $420 \mathrm{~nm}$ using the spectrophotometer. ${ }^{31-32}$ Phosphorus content was determined on lyophilized leaves of S. radicans, reading the absorbance at $650 \mathrm{~nm}$ using ammonium molybdate, hydroquinone and sodium sulphide solutions according to the AOAC method. ${ }^{33}$ S. radicans leaves from the greenhouse were collected at three different times (July and September 2015 and March 2016). The inulin content in these leaves was determined by spectrophotometry, measuring total fructose content, based on the Seliwanoff reaction. ${ }^{34}$ Dry samples were dissolved in $80 \%$ ethanol solution and the extraction procedure was performed by ultrasound with a water bath for 25 minutes. Then, they were left at rest for six hours previously covered so that the solvent did not evaporate. After this time, the extracts were filtered on filter paper and the liquid extracts were evaporated in a rotaevaporator. The liquid extracts that did not evaporate were frozen and then lyophilized, providing extracts rich in inulin. Then, $500 \mathrm{mg}$ of each one of the dry extracts rich in inulin were dissolved in $20 \mathrm{~mL}$ of distilled water, and placed in a water bath $\left(90^{\circ} \mathrm{C}\right)$ for about 10 minutes. Then, $70 \mathrm{~mL}$ of distilled water were added to each one of the flasks and again in a water bath for 30 minutes with occasional shaking. After the time, they were allowed to cool and adjusted to $100 \mathrm{~mL}$. Next, the hydrolysis of the inulin contained in each of the aqueous extracts was carried out into test tubes with $2 \mathrm{~mL}$ of each one of the freshly prepared inulin-rich solutions. Then $1 \mathrm{~mL}$ of resorcinol $(1.00 \mathrm{~g}$ of resorcinol and $0.25 \mathrm{~g}$ of thiourea in $100 \mathrm{ml}$ of glacial acetic acid, and $7 \mathrm{~mL}$ of diluted $\mathrm{HCl}(50 \mathrm{~mL}$ of $\mathrm{HCl}$ with $10 \mathrm{~mL}$ of distilled water) were added. The tubes were vortexed and heated in a water bath $\left(80^{\circ} \mathrm{C}\right)$ for 10 minutes. The solutions were allowed to cool and then the absorbance of each of the pink colored solutions was measured at $520 \mathrm{~nm}$ in a spectrophotometer, using distilled water as the target. The inulin content in the residues under study was calculated from the fructose calibration curve. The calibration curve was linear at concentrations of $0-50 \mu \mathrm{g} \mathrm{mL}^{-1}$ with a correlation coefficient of 0.9903 . To validate the proposed methodology and compare the inulin content obtained from S. radicans, the inulin content was determined in other natural sources. Green asparagus (Asparagus officinalis) and artichoke (Cynara scolymus) were used, which were purchased at a local Supermarket. The total content of phenolics in leaves from $S$. radicans was carried out according to the protocol of Singleton and Rossi, ${ }^{35}$ with some modifications, using gallic acid as a phenolic compound pattern. The method is based on the oxidation-reduction reaction between reducing compounds and the Folin-Ciocalteu reagent (RFC) to form a blue chromophore, a phosphotungstic-phosphomolybdenum complex. Dry leaves $(50 \mathrm{mg}$ ) were extracted with $1 \mathrm{~mL}$ of methanol by sonication for a period of 30 minutes. Then, methanolic extract was centrifuged for 10 minutes at $8,000 \mathrm{rpm}$. For the analysis, $500 \mu \mathrm{L}$ of the obtained methanolic extract were mixed with $250 \mu \mathrm{L}$ of RFC 1:1 (v/v), then, the mixture was shaken gently and the resulting solution was allowed to stand for 5 minutes. Then, $250 \mu \mathrm{L}$ of a $20 \%$ sodium carbonate solution were added to the volumetric flask, the mixture was shaken and the flask was poured with water. Once the solution was obtained, it was allowed to stand for 30 minutes before reading it in the spectrophotometer at $760 \mathrm{~nm}$ against a blank prepared under the same conditions of the sample. The contents of total phenols in the samples were expressed as $\mu \mathrm{mol}$ gallic acid 
equivalents (GAE) per g of dry leaves based on a calibration curve of concentrations with known gallic acid (1-4 $\mu$ g gallic acid $\left.\mathrm{mL}^{-1}\right)$. The calibration curve had a correlation coefficient of 0.9999 . The total flavonoids were determined by the $\mathrm{AlCl}_{3}$ method. ${ }^{36}$ The methodology was based on the reaction between the $\mathrm{OH}$ groups of flavonoids and aluminum $\left(\mathrm{Al}^{+3}\right)$ which forms a pink complex that can be measured spectrophotometrically at $415 \mathrm{~nm}$. The methanol extract of the leaves of $S$. radicans was obtained following the same methodology used in the analysis of total phenolics. Then, $500 \mu \mathrm{L}$ of centrifuged methanolic extract were mixed with $1,5 \mathrm{~mL}$ of ethanol, $100 \mu \mathrm{L}$ of $\mathrm{AlCl}_{3} 10 \%, 100 \mu \mathrm{L}$ of potassium acetate $1 \mathrm{M}$ and $2,8 \mu \mathrm{L}$ of distilled water. The solution obtained was incubated at room temperature for 30 minutes. The results were expressed as $\mu \mathrm{mol}$ quercetin equivalent (QE) per $\mathrm{g}$ of dry leaves based on a calibration curve of concentrations with known quercetin (25-100 $\mu$ g quercetin $\left.\mathrm{mL}^{-1}\right)$. The calibration curve had a correlation coefficient of 0.9953 . The antioxidant activity of methanolic extracts of the $S$. radicans leaves samples was determined by Free Radical Scavenging Assay (DPPH) (2,2-diphenyl-1-picrylhydrazyl) as described in the literature with some modifications. It was prepared a methanolic solution of DPPH at $20 \mathrm{mg} \mathrm{L}^{-1}$. The standard used was Trolox and methanolic solutions were prepared in a concentration range of 0.1 to 2 $\mu \mathrm{g} \mathrm{mL} \mathrm{m}^{-1}$. A calibration curve was created with a correlation coefficient value of 0.9946 . The reaction was initiated by directly incorporating into test tubes, $2940 \mu \mathrm{L}$ of DPPH and $60 \mu \mathrm{L}$ of methanolic extract. The reaction mixtures were incubated for 30 minutes in the dark, and then the absorbances were measured at $517 \mathrm{~nm}$ in a spectrophotometer. The results were expressed as $\mu \mathrm{mol}$ trolox equivalent (TE) per g of dry leaves. Aqueous extracts [decoction, infusion and cold $\left(0{ }^{\circ} \mathrm{C}\right)$ ] were prepared from Selliera radicans leaves to perform the toxicity test on animal cells. The antioxidant capacity of each of the aqueous extracts of the leaves was measured by free radical scavenging assay (DPPH). The scavenging activity of the extracts was estimated using DPPH as the free radical model according to the method adapted from BrandWilliams and collaborators. ${ }^{37}$ Ascorbic acid was used as the reference compound. For this toxicity test on animal cells was used NIH 3T3 mouse embryonic fibroblast cell line, which was cultured in DMEM-H, supplemented with $10 \% \mathrm{FBS}$, streptomycin $\left(100 \mu \mathrm{g} \mathrm{mL}^{-1}\right)$ and penicillin $\left(100 \mathrm{IU} \mathrm{mL}^{-1}\right)$. Cells were seeded in a $100 \mathrm{~mm}$ sterile culture plate with a total volume of $7 \mathrm{~mL}$ of medium DMEM-H. The plate was incubated at $37^{\circ} \mathrm{C}$ with $5 \% \mathrm{CO}_{2}$ in culture oven ( $\mathrm{Hf} 160 \mathrm{~W}$ ). A change of culture medium was performed every day to maintain and expand the cell line, and a harvesting procedure with $1 \mathrm{~mL}$ tripsin-EDTA $0.25 \%$ was used to generate new cell passages. Viability assays were performed as previously described by Zagmutt et $\mathrm{al}^{38}$, using the MTT formazan Kit. NIH 3T3 cell line was seeded in 96 well sterile plates with a cell density of $2.5 \times 10^{4}$ cells/well in $100 \mu \mathrm{L}$ supplemented DMEM-H. Different concentrations of the methanol extract, coming from the decoction aqueous extract, were added based on $\mathrm{IC}_{50}$ value from DPPH assay (122 $\left.\mu \mathrm{g} \mathrm{mL} L^{-1}\right)$.

\section{Statistical analysis}

Each assay was performed in triplicate on three independent assays. All data are presented as mean values \pm standard deviation (SD). For the Viability assays, Variance Analysis of one-way (One-way ANOVA) was used for comparison between groups, and post analysis post hoc Dunnett's was used to compare with the control group or post hoc Bonferroni comparisons between all groups. Differences in $p<0.05$ were considered statistically significant. Data were analyzed and plotted using the computational statistical software GraphPad Prism 4.0.

\section{RESULTS}

The results obtained in the analysis of nutritional and functional characteristics from Selliera radicans leaves are showed in Table 1 and 2. The results displayed that $S$. radicans leaves have similar water, ash, protein, macro and microelements contents to some raw vegetables (Table 3), except for the sodium content which is higher.

\section{DISCUSSION/CONCLUSION}

The nutritional characteristics of cultivated Selliera radicans leaves are shown in Table 1. Its moisture content is comparable to edible plants species such as broccoli, parsley, dandelion, basil, and others. ${ }^{11,39-40}$ This value is within the range for halophytes, for instance, moisture content of Chilean Sarcocornia neei aerial succulent shoots is $86.96 \%$, almost equal to the leaves of cultivated Selliera radicans. ${ }^{42}$ Ash content in Selliera radicans is similar to broccoli and Chinese cabbage. ${ }^{40}$ In general, the percentage of ash in halophytes is characteristically high (2-36\% on dried sample). According to the literature, the percentage of proteins in halophytes comprises values ranging from $6-21 \%$ on a dry weight basis. The protein content in Selliera radicans is within this range and comparable to vegetables consumed daily. ${ }^{11,40-42}$ Macro and micronutrients contents of halophytes depend on several factors, such as the plant species, stage of growth, season, and others. ${ }^{41-42}$

Content of macro and micronutrients in cultivated Selliera radicans leaves are in Table 2 and all these values are lower than cultivated $S$. neei. ${ }^{41}$ For instance, in $100 \mathrm{~g}$ of fresh $S$. neei plants collected in coastal marsh and irrigated with sea water there were $8.07 \mathrm{~g}$ of $\mathrm{Na}^{41}$ while in $S$. radicans there were only $0.66 \mathrm{~g}$ of $\mathrm{Na}$, irrigated with tap water containing $17 \mathrm{mg} \mathrm{L}^{-1}$ sodium.

The leaves from cultivated Selliera radicans are a good source of carbohydrates, total phenolics and flavonoids, and antioxidant activity (Table 1). Likewise, the results indicate that leaves are a source of inulin, a prebiotic fiber with powerful health properties. This value is similar to values found in artichokes (1.7\%) and asparagus (2.5\%), species cultivated worldwide as food source.

In Table 3 the nutrition content from Selliera radicans leaves was compared with some vegetables commonly consumed in the world. ${ }^{40}$ In comparison to asparagus (Asparagus officinalis), broccoli (Brassica oleracea var. italica), Chinese cabbage (Brassica rapa subsp. pekinensis), alfalfa sprouts (Medicago sativa), and spinach (Spinacia oleracea), Selliera radicans has higher values for $\mathrm{Ca}, \mathrm{Mg}$ and $\mathrm{Na}$. Phosphorous

Table 1: Main physicochemical data related to nutritional and functional characteristics of cultivated Selliera radicans leaves.

\begin{tabular}{lc}
\hline \multicolumn{1}{c}{ Parameter } & Content \\
\hline Proximate & \\
Moisture & $87.8 \pm 3.2 \%$ \\
Dry matter & $12.2 \pm 3.2 \%$ \\
Ash & $6.8 \pm 0.1 \% \mathrm{DW}$ \\
Protein & $7.5 \pm 0.3 \% \mathrm{DW}$ \\
Total carbohydrates & $14.2 \pm 1.3 \%$ \\
Health promoting substances & \\
Inulin & $2.3 \pm 1.0(\% \mathrm{DW})$ \\
Total phenolics & $63.4 \pm 1.0(\mathrm{GAE} / \mathrm{g} \mathrm{LDW})$ \\
Total flavonoids & $21.8 \pm 0.3(\mathrm{QE} / \mathrm{g} \mathrm{LDW})$ \\
Antioxidant activity & $10.0 \pm 0.2(\mathrm{TE} / \mathrm{g} \mathrm{LDW})$ \\
\hline
\end{tabular}

DME $=$ Dry methanolic extract DW $=$ Dry weight $; \mathrm{GAE}=$ Gallic acid equivalent; $\mathrm{QE}=$ Quercetin equivalent; $\mathrm{LDW}=$ Leaves in dry weight; $\mathrm{TE}=$ Trolox Equivalent.

Table 2: Macro and micronutrients of cultivated Selliera radicans leaves.

\begin{tabular}{cccc}
\hline Macronutrients & $\%$ & Micronutrients & $\mathrm{mg} \mathrm{kg}^{-1}$ \\
\hline $\mathrm{Ca}$ & 0.92 & $\mathrm{~B}$ & 68 \\
$\mathrm{~K}$ & 2.62 & $\mathrm{Cu}$ & 8 \\
$\mathrm{Na}$ & 5.42 & $\mathrm{Fe}$ & 75 \\
$\mathrm{Mg}$ & 0.82 & $\mathrm{Mn}$ & 41 \\
$\mathrm{P}$ & 0.20 & $\mathrm{Zn}$ & 29 \\
\hline
\end{tabular}


Table 3: Comparison of nutritional values of raw cultivated Selliera radicans and some raw vegetables."

\begin{tabular}{cccccccc}
\hline Content & $\begin{array}{c}\text { Selliera } \\
\text { radicans }\end{array}$ & Alfalfa sprouts & Asparagus & Broccoli & $\begin{array}{c}\text { Chinese } \\
\text { Cabbage }\end{array}$ & Spinach & Watercress \\
\hline Water $(\mathrm{g})$ & 87.8 & 92.8 & 93.22 & 90 & 95.32 & 91.4 & 95.11 \\
Protein $(\mathrm{g})$ & 2 & 3.99 & 2.2 & 2.57 & 1.5 & 2.86 & 2.3 \\
$\mathrm{Ash}(\mathrm{g})$ & 0.83 & - & 0.58 & 0.83 & 0.8 & 1.72 & 1.2 \\
$\mathrm{Ca}(\mathrm{mg})$ & 110 & 32 & 24 & 46 & 105 & 99 & 120 \\
$\mathrm{Fe}(\mathrm{mg})$ & 0.92 & 0.96 & 2.14 & 0.69 & 0.8 & 2.71 & 0.2 \\
$\mathrm{Mg}(\mathrm{mg})$ & 100 & 26 & 14 & 21 & 19 & 79 & 21 \\
$\mathrm{P}(\mathrm{mg})$ & 24.4 & 70 & 52 & 67 & 37 & 49 & 60 \\
$\mathrm{~K}(\mathrm{mg})$ & 320 & 79 & 202 & 303 & 252 & 558 & 330 \\
$\mathrm{Na}(\mathrm{mg})$ & 660 & 6 & 2 & 36 & 65 & 79 & 41 \\
$\mathrm{Zn}(\mathrm{mg})$ & 0.35 & 0.92 & 0.54 & 0.42 & 0.19 & 0.53 & 0.11 \\
$\mathrm{Cu}(\mathrm{mg})$ & 0.1 & 0.157 & 0.189 & 0.059 & 0.021 & 0.13 & 0.077 \\
$\mathrm{Mn}(\mathrm{mg})$ & 0.5 & - & 0.158 & 0.197 & 0.159 & 0.90 & 0.244 \\
\hline
\end{tabular}

${ }^{*} 100$ g, FoodData Central Published date (USDA, 2019). "(pak-choi).

content was the only mineral that had a lower value compared to other vegetables.

Among the three aqueous extracts prepared, the one obtained by decoction was chosen to perform the toxicity test because it had the lowest $\mathrm{IC}_{50}$ value. The cell viability was not affected by the extract, even at the highest concentration at $488 \mu \mathrm{g} \mathrm{mL}^{-1}$. The toxicity test helped to confirm that this plant does not harm mammalian cells and supports the thesis that the earlier inhabitants of Monte Verde consumed this plant.

Under the global warming scenario, new sources of food are needed to ensure food availability. ${ }^{6}$ The edible plants species that can cope with environmental stress factors could be a great approach. According to the results, Selliera radicans may be a potential new source of food with health benefits. This is the first report about nutritional and functional study of Selliera radicans.

The nutritional and functional preliminary analysis revealed that cultivated Selliera radicans leaves are an important source of ash, proteins, $\mathrm{B}, \mathrm{Ca}, \mathrm{Cu}, \mathrm{Fe}, \mathrm{K}, \mathrm{Na}, \mathrm{Mg}, \mathrm{Mn}, \mathrm{P}, \mathrm{Zn}$, inulin, total phenolics and flavonoids, and antioxidant capacity. Given the nutritional and functional characteristics of Selliera radicans leaves, it may be considered a promising source of food with healthy beneficial properties.

\section{ACKNOWLEDGEMENTS}

We wish to thank Mr. Sergio Reyes for his help in the laboratory analyses, and Dr. Iván R Razmilic for providing a great part of the equipment needed for this research. Thanks to Rachael Jiménez-Lange, Language Program of Universidad de Talca and Jeffrey Hogue, $\mathrm{PhD}$ in Plant Pathology, Cornell University, for revising the English version of the manuscript

\section{CONFLICTS OF INTEREST}

No potential conflict of interest was reported by the authors.

\section{REFERENCES}

1. Velásquez P, Montenegro G. Chilean Endemic/Native Plant Resources as Functional and Superfoods. In: Waisundara V, Shiomi N, Editors. Superfood and Functional Food - An Overview of Their Processing and Utilization. Croatia: IntechOpen. 2017;131-54.

2. Ulloa-Inostroza E, Ulloa-Inostroza EG, Alberdi M, Peña-Sanhueza D, Gónzalez-Villagra J, Jaakola L, et al. Native Chilean Fruits and the Effects of their Functional Compounds on Human Health. In: Waisundara V, Shiomi N, Editors. Superfood and Functional Food - An Overview of Their Processing and Utilization. Croatia: IntechOpen. 2017:99-130.
3. Díaz-Forestier J, León-Lobos $P$, Marticorena A, Celis-Diez JL, Giovannini P. Native Useful Plants of Chile: A Review and Use Pattern. Economic Botany. 2019;1:112-26.

4. Orrego F, De la Fuente LM, Gómez M, Ginocchio R. Diversity of Chilean halophytes: distribution, origin and habit. Gayana Botánica. 2018;75:555-67.

5. Flowers TJ, Colmer TD. Salinity tolerance in halophytes. New Phytologist. 2008;179:945-63.

6. Galvani A. The challenge of the food sufficiency through salt tolerant crops. Reviews Environmental Science and Biotechnology. 2007;6:316.

7. Glenn EP, Brown JJ. Blumwald E. Salt tolerance and crop potential of halophytes. Critical Reviews in Plant Sciences. 1999;18,227-55.

8. Shamsutdinov NZ, Shamsutdinova EZ, Orlovsky NS, Shamsutdinov ZSh. Halophytes: Ecological features, global resources, and outlook for multipurpose use. Herald of the Russian Academy of Science. 2017:87:1-11

9. Ksouri R, Megdiche W, Jallali I, Debez A, Magné C, Hiroko I, et al. Medicinal halophytes: potent source of health promoting biomolecules with medical, nutraceutical and food applications. Critical Reviews in Biotechnology. 2012;32(4):289-326.

10. Sharma R, Wungrampha, S, Singh, V, Pareek A, Sharma MK. Halophytes as bioenergy crops. Frontier in Plant Science. 2016;7:1372.

11. Oasim M, Abideen Z, Adnan MY, Gulzar S, Gul B, Rasheed M, et al. Antioxidant properties, phenolic composition, bioactive compounds and nutritive value of medicinal halophytes commonly used as herbal teas. South African Journal of Botany. 2017;110:240-250.

12. Barreira L, Resek E, Rodrigues MJ, Pereira H, Varela J, Custo囚dio $\mathrm{L}$, et al. Halophytes: Gourmet food with nutritional health benefits? Journal of Food Composition and Analysis. 2017;59:35-42.

13. Petropoulos, SA, Karkanis A, Martins N, Ferreira, ICFR. Edible halophytes of the Mediterranean basin: potential candidates for novel food products. Trends Food Science and Technology. 2018;74:69-84.

14. Abd ME, El-Hack DH, Samak AE, Noreldin M, Arif HS, Yaqoob AA. Towards saving freshwater: halophytes as unconventional feedstuffs in livestock feed: a review. Environmental Science Pollution Research. 2018;25:14397-406.

15. Barr A, Chapman J, Smith N, Wightman G, Knight T, Mills L, et al. Traditional Aboriginal medicines in the Northern Territory of Australia. Aboriginal Communities of the Northern Territory. Darwin: Conservation Commission of the Northern Territory; 1993.

16. Cambie RC. Antifertility plants of the Pacific. Collingwood, Australia: CSIRO Publishing; 1997.

17. Ghisalberti E. Review. The Goodeniaceae. Fitoterapia 2004;75:42946.

18. Kerr P. Phytochemical investigations of species of semi-arid Australian plants: A neglected area of research. Pharmacognosy Communications. 2012;2:1-3. 
19. Barrett RL, Barrett MD. Four new species of Goodeniaceae from Western Australia, including the smallest species in the family, a putative seed-article elaiosome and possible floral mimicry in Lechenaultia, Australian Systematic Botany. 2015;27:469-82.

20. Rai M, Harisha CR, Fichadiya G, Dudhamal TS, Thagele V. Pharmacognostical profile of Scaevola taccada (gaertn.) roxb. (leaf and stem) - an extra pharmacopoeia drug. World Journal of Pharmaceutical Research. 2017;6:552-58.

21. Weber $\mathrm{H}$. Haben die Marcgraviaceen Inulinblatter? Berichte der Deutschen Botanischen Gesellschaft. 1955;68:408-12.

22. Allan HH. Flora of New Zealand: Indigenous Tracheophyta, Psilopsida, Lycopsida, Filicopsida, Gymnospermae, Dicotyledones. Wellington, New Zealand: Government Printer;1961.

23. Dillehay TD, Ramírez C, Pino M, Collins MB, Rosen J, Pino-Navarro JD. Monte Verde: Seaweed, Food, Medicine, and the Peopling of South America. Science. 2008;320:784-786.

24. Dillehay TD. Ocampo C, Saavedra J, Sawakuchi AO, Vega RM, Pino $M$, et al. New archaeological evidence for an early human presence at Monte Verde, Chile. PLOS ONE. 2015;10:1-27.

25. Schiappacasse F. Rodriguez E, Nektarios PA, Gaete K, Maturana L. Growth of the Chilean plants Haplopappus macrocephalus and Selliera radicans on an extensive modular green roof system under three irrigation regimes. Idesia. 2017;35:31-39.

26. AOAC International. Official Methods of Analysis. (16th ed.). Gaithersburg, MD: AOAC International. 1998a.

27. AOAC International. Official methods of analysis (16th ed.). Gaithersburg, MD: AOAC International. 1998b;5.

28. Morse EE. Anthrone in estimating low concentrations of sucrose. Analytical Chemistry. 1947;19:1012-1013.

29. Watson ME, GalliherTL. Comparison of Dumas and Kjeldahl methods with automatic analyzers on agricultural samples under routine rapid analysis conditions. Communications in Soil Science and Plant Analysis. 2006;32:2007-2019.

30. Fernandez-Hernandez A, Mateos R, Garcia-Mesa JA, Beltran G, Fernandez-Escobar R. Determination of mineral elements in fresh olive fruits by flame atomic spectrometry. Spanish Journal of Agricultural Research. 2010;8(4):1183-90.
31. Wolf B. The determination of boron in soil extracts, plant materials, composts, manures, water, and nutrient solutions. Communications in Soil Science and Plant Analysis. 1971;2:363-74.

32. Gupta UC. Some factors affecting the determination of hot-watersoluble boron from podzol soils using azomethine- $\mathrm{H}$. Canadian Journal of Soil Science.1979;59:241-247.

33. AOAC, Association of Official Analytical Chemists. Official methods of Analysis, 15th ed. Method Number 931.01 (phosphorus), Arlington, VA; 1990.

34. Sánchez-Viesca F, Gómez R. Reactivities Involved in the Seliwanoff Reaction. Modern Chemistry. 2018;6:1-5

35. Singleton VL, Rossi JA. Colorimetry of total phenolics with phosphomolybdic-phosphotungstic acid reagents. American Journal of Enology Viticulture. 1965;16:144-58.

36. Zhishen J, Mengcheng T, Jianming W. The determination of flavonoid contents in mulberry and their scavenging effect on superoxide radicals. Food Chemistry.1999;64:555-9.

37. Brand-Williams W, Cuvelier ME, Berset C. Use of a free radical method to evaluate antioxidant activity. LWT-Food Science and Technology. 1995;28:25-30.

38. Zagmutt S, Leiva E, Mujica V, Wehinger S. Protective effect of propolis extract on pancreatic $\beta$ cell under oxidative stress in vitro. Journal of Food and Nutrition Research. 2016;4:400-7.

39. Yang RY, Lin S, Kuo G. Content and distribution of flavonoids among 91 edible plant species. Asia Pacific Journal Clinical Nutrition. 2008; 17:275-9

40. USDA. 2019. Available from: https://fdc.nal.usda.gov/index.html

41. Riquelme J, Olaeta JA, Gálvez L, Undurraga P, Fuentealba C, Osses A, et al. Nutritional and functional characterization of wild and cultivated Sarcocornia neei grown in Chile. Ciencia e Investigación Agraria. 2016;43(2):283-93

42. Attia-Ismail SA. Role of Minerals in Halophyte Feeding to Ruminants. In: Prasat MNV, Editor. Trace Elements as Contaminants and Nutrients: Consequences in Ecosystems and Human Health. New Jersey, NJ: John Wiley \& Sons, Inc. 2008;701-20.

\section{GRAPHICAL ABSTRACT}

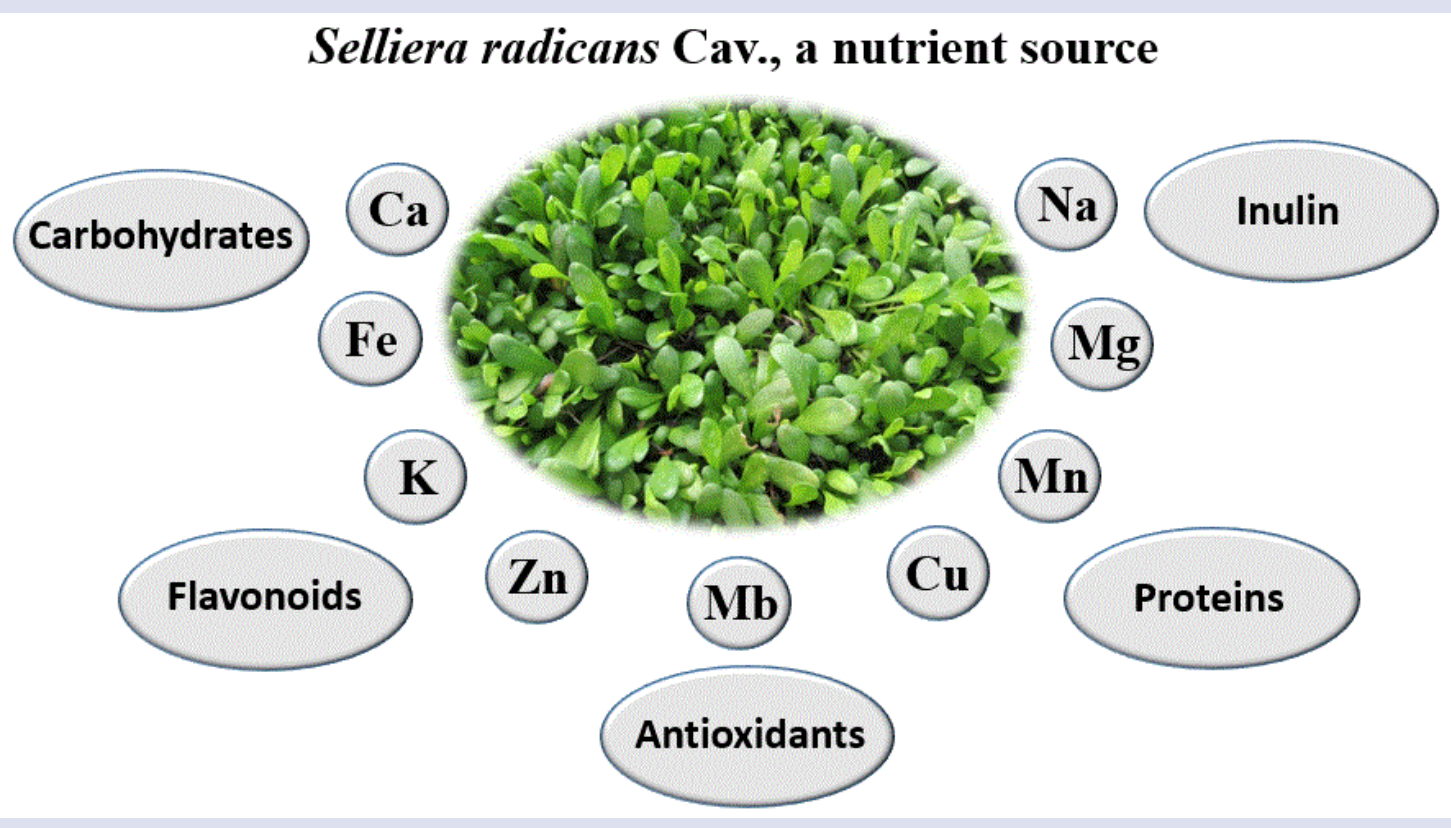




\section{ABOUT AUTHORS}

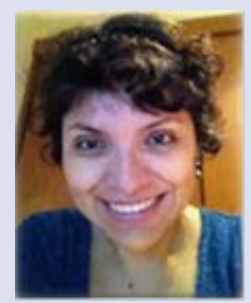

Maria del Pilar Caramantin Soriano: She graduated at University of Engineering, Peru, with a B.S. degree in Chemistry and obtained a PhD in Science from University of Campinas, Brazil. She is professor in University of Talca, participating in two graduate programs of this institution, and also teaches at undergraduate level. She has research interests in phytochemistry and biological activities of native plants, and new methodologies about learning science. She had published several papers with regard to natural products and organic synthesis.

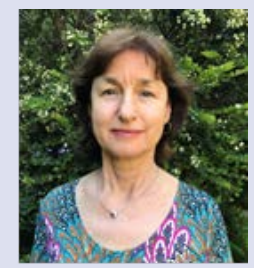

Flavia Schiappacasse: Agronomist, has completed her M.S. in Floriculture and ornamental horticulture at Cornell University, U.S.A. She is Associate Professor at University of Talca, with more than 25 years of teaching experience at undergraduate and graduate levels, and conducting research on cut flowers, Chilean geophytes and Proteaceae species. Since 2008 she is part of the organizing committee of the Chilean Native flora National congress.

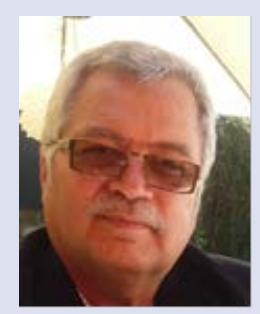

Dr. Patricio Peñailillo, Botanist, retired professor of University of Talca. He did research on grass taxonomy (tribe Stipeae of South America), biology of Chilean bulbs, vascular plants biodiversity of Maule region, and plant evolution in islands (Archipelago of Juan Fernandez). Author and coauthor of several publications and participated in both national and international projects.

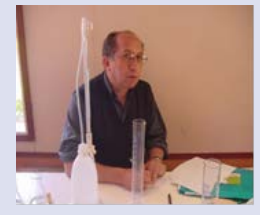

Dr. Jaime Tapia S. is Analytical Chemist, and Associate Professor at the University of Talca, Chile. Currently Director of the Institute of Natural Resources Chemistry. He has over thirty-five years of teaching experience. He has directed over 30 undergraduate and graduate theses on topics related to the quantification of heavy metals at trace level by atomic absorption spectroscopy in different types of environmental matrices, using bioindicators of animal or vegetable origin. He has over fifty scientific publications in mainstream journals, ISI-SCOPUS category.

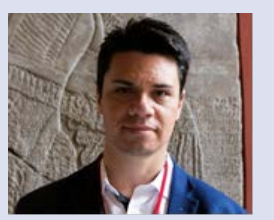

Dr. Sergio Wehinger has completed his PhD in Biomedical Sciences at University of Chile in 2013. Today he is Associate Professor, and Director of the Magister program in Biomedical Sciences at University of Talca, lecturing in two doctorate programs of this institution. Dr. Wehinger has published several papers about chronic diseases and currently he is conducting research on molecular mechanisms involved in aging and in chronic diseases such as diabetes and endothelial dysfunction.

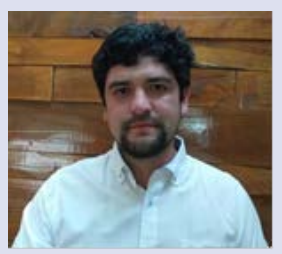

Camilo A. Valenzuela Vásquez: He graduated in Agronomy at University of Talca, Chile, in 2015.

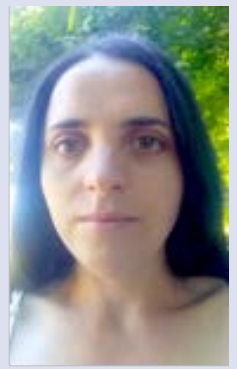

Sarvia M. Durán Peña: She graduated in Agronomy at University of Talca, Chile, in 2016.

Cite this article: Soriano MDPC, Schiappacasse F, Penailillo P, Tapia J, Wehinger S, Valenzuela-Vasquez CA, et al. Nutritional and Functional Potential of Selliera radicans Cav., a Chilean Native Halophyte. Pharmacog J. 2021;13(2): 341-6. 